\title{
Accidents related to the use of products and services in the city of São Luis, Brazil
}

\author{
Líssia Maria De Souza Dias ${ }^{a^{*}}$, Raimundo Lopes Diniz ${ }^{\mathrm{b}}$ and Lia Buarque de Macedo Guimarães ${ }^{\mathrm{c}}$ \\ $a^{*}$ Santa Terezinha College - Maranhão - Brazil \\ ${ }^{\mathrm{b}}$ Department of Design and Technology, Graduation Program in Health and Environment \\ Federal University of Maranhão - Brazil, diniz@ufma.br

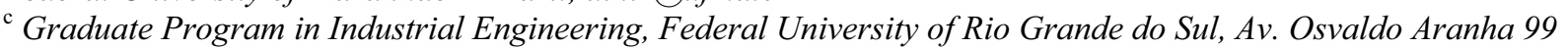 \\ $5^{\circ}$ andar, Porto Alegre, RS, 90035-190,Brazil, liabmg@gmail.com
}

\begin{abstract}
This article presents a study on the accidents related to the use of products and services, as recorded at two emergency hospitals at the city São Luís, Brazil. The goal of the study was to evaluate the main types and causes of unintentional acccidents as well as the more frequent injuries for further improvement of products and services. The study evaluated the victims profile (gender and age), the circumstances (activity, local and time) that lead to the accidents and the type of resulted injury. Non-parametric statistics showed that $83.64 \%$ of the accidents were related to products $(57.6 \%$ of them being consumer products) and $8.6 \%$ are related to maintenance services. $57.6 \%$ of the victims were children under 15 years old, and $58.4 \%$ were male. $50.2 \%$ of accidents occurred at home, more often $(44.7 \%)$ in the afternoon. The most common injuriy was musculoesqueletal (48.6\%), $49.0 \%$ being cranioencephalic trauma and $15.2 \%$ fractures.
\end{abstract}

Keywords: accidents, product, service, injuries.

\section{Introduction}

Based on the Brazilian Code for Consumer Protection $[2\}$, "consumer accidents" may be undestand as any harm caused by products or services to their users or to others. Article 6 in chapter III of the Code states that "consumers has the right to have their lives, health and safety protected against the risk imposed by all practices related to the provision of products and services considered dangerous or pernicious" [2]. The Brazilian Institute for the Defense of Cosummers (IDEC) refer to "consumer accidents" as to any defect on a product or a service that, in addition to causing a malfunction, is capable of generating physical harm to the user or to others, even when used or handled correctly [12]. In order to enhance public awareness on consumer rights, IDEC maintains an on online site with general and specific information for the public, and publishes guides on both the social
[11] and environmental [10] responsibilities of products/services consumers. Dolci [6] published a guide on accidets with consumer products based on her research carried out in the city of São Paulo.

However, despite the law and the guides related to the use of products and services, Brazilian consumers do not know their rights or do not think their rights will be guaranteed therefore there is no database on consumer accidents. According to IDEC [12] while the American Consumer Product Safety Comission (CPSC) has a database for over 30 years, there are no data on consumers accidents available in Brazil. The CPSC estimates that the losses generated from consumer accidents are around U\$700 billion/year [12]. Recently, IDEC suggeted to the Brazilian Institute for Metrology (INMETRO) [14] the development of an accidents database, where consumers can report the case on line either through the INMETRO [15] or IDEC [13] sites. This is an effort to estimate

*lissiadias@yahoo.com.br 
both the social and economic costs of consumer accidents in Brazil, and a source of information for revising norms and improving the quality of products and services. Norms should be used not only for inspection but also for consumers education [12].

So far, there are few researches conducted in Brazil focusing the relationship between product and consumers, and evaluating whether the products meet the minimum standards of safety and sustainability [17]. One study was conducted by Dolci [5], in 2003, aiming to map the incidence and events of accidents caused by products and services that required hospital medical care involving multiple partners in Research hospitals in the city of São Paulo. Baracat et al. [1] evaluated accidents with children in Campinas, state of São Paulo, and Salponik [16] in the city of Salvador, state of Bahia; Deslandes and Silva [4] conducted a study in two public hospitals and Freitas et al. [7] in one hospital, both studies in the city of Rio de Janeiro, to evaluate traffic-related accidents.

This article presents a study on the accidents related to the use of products and services in the city of São Luis, state of Maranhão, Brazil, as recorded by two emergency hospitals. The study is a segment of a project sponsored by CNPq (Brazilian National Council of Research and Development), from August 2006 to 2008 to identify problems with products and services that affect the population of the cities of Porto Alegre, in the south of the country, and São Luiz, in the northeast, and compare the results focusing the socioeconomic differences. The full report [8] details the main causes and types of accidents as well as the more frequent injuries for diagnosing the problems and, further, to contribute for the improvement of products and services. The following sections present only the results obtained in São Luis.

\section{Method}

The study can be characterized as cross-sectional descriptive with a sample of 257 respondents from two emergency hospitals, one public and the other private, with no comparison between the hospitals' results. The instrument used for data collection was a standardized interview, following a semi-structured form, adapted by Guimarães and Ballardin [9] from the British Accident Home Surveillance System (HASS) form [3]. Data collection took place from October 2007 to February 2008.

The inclusion criteria were all patients of any age, who had suffered any kind of accident related to products and/or services. Product-type accidents included furniture, household items, chemicals, electronics and appliances, work tools, toys, vehicles, medicines and various objects. Construction, general maintenance and transport were classified as Services. The patients admitted in emergencies, victims of accidents caused by acute or chronic illnesses, victims of physical assault, suicide or any other circumstances that so distort the nature of the study were excluded from the study.

The sample was composed by 257 cases, 252 $(97.3 \%)$ from the public hospital and $7(2.7 \%)$ from the private one. The evaluated variables were the type of accident (product or service), the accident circumstances (local and time), the type of injury, the body part affected and the victims profile (gender and age). Data collected in the semi-structured form were coded, classified and tabulated in an Excel spreadsheet. Because data did not show normal distribution, they were analyzed by descriptive statistics (frequencies and measures of central tendency and dispersion) and nonparametric test using the Statistical Package for the Social Sciences (SPSS 16.0). Fisher's exact test and contingency tables were used to compare the observed and expected frequencies. Spearman coefficient was used to evaluate the direction and degree of association between two variables, measured either at ordinal or categorical level. Analysis was done considering a $95 \%$ confidence level (i.e. statistical significance of $\mathrm{p}<0.05$ ).

\section{Results}

From a total of $83.64 \%$ product related accidents, $57.6 \%$ ocurred with consumer products (Figure 1). Vehicles were the products leading to the highest rate of accidents $(20.87 \%)$ followed by tools and equipment (13.48\%) and the built environment (12.61\%). Maintenance services corresponded to $8.6 \%$ of the accidents. The most common injuries were musculoesqueletal $(48.6 \%), 49.0 \%$ being cranioencephalic trauma and $15.2 \%$ being fractures. A similar study conducted by Dolci [5], in São Paulo, involving 2,021 accident victims attended at four emergency hospitals, noted that $73 \%$ of the accidents were related to products and services, $27 \%$ of them being consumer products.

$57.5 \%$ of the victims were children (age 1 to 14 years old) and $58.4 \%$ were male. Spearman test showed a significant association between the type of injury and age $(p=0.001)$ and gender $(p=0.033)$. From 
table 1 , it is observed that adult males had a higher percentage of accidents with product-type vehicle. Deslandes and Silva [4] found that $69.3 \%$ of the victims of traffic accidents were male and the most affected age group was $20-39$ years $(60.5 \%$ in one hospital and $47.5 \%$ in the other). Freitas et al. [7] noted the predominance of males $(65.7 \%)$ of different ages (mean age 8 to 41 years) as victims of traffic accidents involving two vehicles and four wheels.

The results showed that $50.2 \%$ of the accidents occurred at home and $30.7 \%$ in public areas. Accidents occurred more often during domestic activities $(44.4 \%)$ and in the afternoon (44.7\%). Salponik [16] found that in $56.9 \%$ of the evaluated accidents, $37.9 \%$ happened in public roads and $37.9 \%$ at home. Spearman test showed significant association between the local of accident and gender $(p=0.002)$ and age $(\mathrm{p}<0.000)$. Men have accidents in the industry (where they work) while women at home (where they work). Accidents with people at age 10 to 14 years happened more often at home (where they live and play). A study by Waisman et al. [18] also related the accident site with age: $89.5 \%$ of accidents occurred at home with children under one year old, while $5 \%$ of accidents occur at the same age in public spaces.

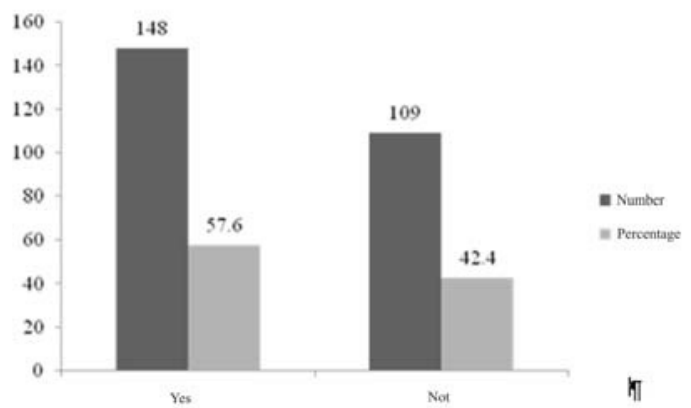

Fig. 1 Occurrence of accidents with consumer products as evaluated at two hospitals in São Luis $(n=257)$.

Table 1

Distribution of products and services related to gender and age range as evaluated at two hospitals in São Luis $(n=257)$.

\begin{tabular}{|c|c|c|c|c|c|c|c|}
\hline \multirow{2}{*}{\multicolumn{2}{|c|}{ Product }} & \multicolumn{2}{|c|}{ Gender $(\%)$} & \multicolumn{4}{|c|}{ Age $(\%)$} \\
\hline & & \multirow{2}{*}{$\begin{array}{l}\text { Male } \\
23.2\end{array}$} & \multirow{2}{*}{$\begin{array}{l}\text { Female } \\
12.1\end{array}$} & \multirow{2}{*}{$\begin{array}{l}\text { Child } \\
11.6\end{array}$} & \multirow{2}{*}{$\begin{array}{l}\text { Adolescent } \\
23.0\end{array}$} & \multirow{2}{*}{$\begin{array}{l}\text { Adult } \\
29.5\end{array}$} & \multirow{2}{*}{$\begin{array}{l}\text { Elderly } \\
17.6\end{array}$} \\
\hline 1 & Vehicles & & & & & & \\
\hline 2 & Built Environment & 6.7 & 17.8 & 8.6 & 15.4 & 11.5 & 29.4 \\
\hline 3 & Furniture & 4.7 & 10.3 & 7.9 & 0.0 & 4.5 & 17.6 \\
\hline 4 & Household items & 4.7 & 9.3 & 9.4 & 0.0 & 4.5 & 0.0 \\
\hline 5 & Work tools & 8.0 & 1.9 & 0.7 & 0.0 & 13.6 & 5.9 \\
\hline 6 & Electronics & 0.7 & 0.0 & 0.7 & 0.0 & 0.0 & 0.0 \\
\hline 7 & Trees & 13.2 & 4.7 & 13.8 & 15.4 & 4.5 & 0.0 \\
\hline 8 & Toys & 6.7 & 3.7 & 8.6 & 15.4 & 0.0 & 0.0 \\
\hline 9 & Fire & 4.7 & 4.7 & 7.9 & 7.7 & 0.0 & 0.0 \\
\hline 10 & $\begin{array}{l}\text { Other } \\
\text { Personal Household }\end{array}$ & 8.0 & 4.7 & 5.0 & 7.7 & 8.0 & 11.8 \\
\hline 11 & $\begin{array}{l}\text { Personal Household } \\
\text { items }\end{array}$ & 0.7 & 10.3 & 5.0 & 0.0 & 4.5 & 5.9 \\
\hline 12 & Chemicals & 4.0 & 2.8 & 4.3 & 0.0 & 3.5 & 0.0 \\
\hline 13 & Medicines & 0.7 & 0.9 & 0.7 & 0.0 & 1.1 & 0.0 \\
\hline 14 & Various Objects & 4.0 & 5.6 & 7.2 & 7.7 & 1.1 & 0.0 \\
\hline 15 & Services- Reform & 0.0 & 0.9 & 0.7 & 0.0 & 0.0 & 0.0 \\
\hline 16 & Services-Maintenance & 9.3 & 7.5 & 7.2 & 7.7 & 10.2 & 11.8 \\
\hline 17 & Services-Transport & 0.7 & 2.8 & 0.7 & 0.0 & 3.5 & 0.0 \\
\hline
\end{tabular}

Although there was no significant association between the part of the body injured and gender $(p=0.209)$, there was association with age $(p=0.009)$. Children with age between 1 and 4 years old hurt the head. Adults from 30 to 39 years old hurt the limbs. The elderly (70 to 79 years old) hurt two or more body parts.

In the built environment (including steps, stairs, floor, ceramic tiles, among others) accidents happen more often with female and children. The female children were the victims with the highest percentage of accidents caused by moving objects, including chairs, beds, benches, etc. No record was found in the literature to corroborate these findings. The accidents were caused mainly by falls $(68.9 \%$ of the cases) due to difference in levels (51.8\%). Dolci [5] also found that children under five years old were the main victims of accidents with products and services; the falls were the leading cause of injuries like cutting; home and street were the main sites of accidents, that happened mainly in the morning and afternoon. The most affected body segments were the head and upper and lower limbs. Watson et al. [19] confirm that the most frequent accidents are associated with slips and falls on concrete surfaces (indoors or outdoors) and structural features of the house.

Adolescents and male children were the main victims of accidents involving trees. The practice of climbing trees as a leisure activity, allows the occurrence of accidents among children and adolescents. No references were found in the literature to reinforce or contradict these findings. This result is probably a characteristic of São Luis, a town not too much industrialized, where children still keep the tradition of playing outdoors in close contact with nature. Also, adolescents and children, especially males, were the main victims of accidents involving toys. Some products may be appropriate for users of certain age, but are not suitable for others. For exam- 
ple, a toy intended for children may not contain parts that can break off and be swallowed. Dolci [5] found that children (38\%) have accidents with toys $(60 \%)$ and are victims of obstruction of the airways.

Items related to home appliances and electronics, as well as reform services, transport services and medications, had little expression. Products such as food and drinks were not recorded in this study.

Regarding the body part injured, the upper and lower limbs were the most affected $(33.5 \%)$ followed by the head $(26.5 \%)$. Baracat et al. [1] also found that the upper and lower limbs were the most affected body parts, accounting for $40.7 \%$ of the accidents in the sample studied. Freitas et al. [7] found that the upper and lower limbs accounted for $42 \%$ of the injured body part.

\section{Conclusion}

In the research conducted in two hospitals in São Luis, State of Maranhão, Brazil, there was a higher rate of accidents related to consumer products than services, accidents occurring mainly in the afternoon. The most frequent site was the home and the activity with the highest rate of accidents was domestic. The vehicles were the main causes of accidents followed by the built environment. Males were the most affected and the children were the main victims of accidents. The body segments most affected were the upper and/or lower limbs and the lesions were the most common type of injury found in the study.

Studies on accidents related to consumer products and/or services are rare in Brazil, although they are essential to improve the quality of goods and safety of the consumers. Brazil is a big country, with very different characteristics, needs and challenges among its five geographic regions. A similar study in hospitals in the south of the country using the same method (same protocol and statistical analysis) showed different results. Therefore, local studies are crucial for undercovering the reality of accidents in different regions of the country, given their socio-economic and cultural differences. The results should be made available to regulatory bodies, industry and society in general, so actions can be taken to prevent accidents and optimize the conditions for use of products and services, therefore minimizing the risk of both physical and emotional trauma caused by accidents.

\section{Acknowledgments}

This research was partly developed with a grant from the Brazilian National Council for Research and Development $(\mathrm{CNPq})$. The authours are grateful to Patricia Keiser Biasolli for the statistical support.

\section{References}

[1] E. C. E. Baracat, K. Paraschin, R.J.N. Nogueira, M.C. Reis, A M. A. Fraga, Reis and G. Sperotto, Acidentes com crianças e sua evolução na região de Campinas. Jornal de Pediatria, São $\begin{array}{lllll}\text { Paulo, } & 76 & \text { (5) } & \text { (2000), }\end{array}$ http://www.criancasegura.com.br/downloads/pesquisa/Artigo \%2012.pdf Accessed 15 September 2011.

[2] Brasil, Presidencia da Republica, Law No 8.078, of September 1990. http://www.planalto.gov.br/ccivil 03/LEIS/L8078.htm Accessed September 102011.

[3] Department of Trade and Industry - DTI (1998) Home Accident Surveillance System (HASS) 20th Annual Report. London: Department of Trade and Industry.

[4] S. F. Deslandes and C. M. F. P. Silva, Análise da morbidade hospitalar por acidentes de trânsito em hospitais públicos do Rio de Janeiro. Revista de Saúde Pública, São Paulo, v. 34, n. 4, p. 367-372, ago. 2000.

[5] M. Dolci, Acidentes de consumo: mobilização e prioridades para a defesa do consumidor, in II Seminário da Associacao Brasileira de Defesa do Consumidor Protest, 2, 2004. São Paulo. http://www.proteste.org.br/20060106/relatorio-com-osresultados-da-pesquisa-acidentes-de-consumoAttach_s422291.pdf Accessed September 152011.

[6] M. Dolci, Acidentes de consumo . Associacao Medica Brasileira and Associacao Pro Teste. 2005 http://www.amb.org.br/acidentes.pdf Accessed September 15 2011.

[7] J.P.P. Freitas, L.A. Ribeiro and J.M.Tanus, Vítimas de acidentes de trânsito na faixa etária pediátrica atendidas em um hospital universitário: aspectos epidemiológicos e clínicos. Cad. Saúde Pública. Rio de Janeiro, 23 (12) (2007): 30553060 .

[8] L.B. de M. Guimarães, Report of the project "The problems of product safety: an analysis based on accidents reported in ANVISA (Brazilian Agency for Sanitary Vigilance), the hospital system and organs of consumer law." Sponsored by $\mathrm{CNPq}$ - Brazilian National Council for Research and Development. 2006.

[9] L.B. de M. Guimarães and L. Ballardin, Adaptation of the Home Accident Surveillance System (HASS). Report of the project "The problems of product safety: an analysis based on accidents reported in ANVISA (Brazilian Agency for Sanitary Vigilance), the hospital system and organs of consumer law." Sponsored by $\mathrm{CNPq}$ - Brazilian National Council for Research and Development. 2006.

[10] IDEC Instituto Brasileiro de Defesa do Consumidor, Meio ambiente e consumo, Brasília: INMETRO, 2002. (Coleção educação para o consumo sustentável). http://www.inmetro.gov.br/infotec/publicacoes/cartilhas/ColE ducativa/meioambiente.pdf Accessed September 52011

[11] IDEC Instituto Brasileiro de Defesa do Consumidor, Guia de Responsabilidade Social para o Consumidor. São Paulo, 2004. http://www.idec.org.br/arquivos/guia_RSE.pdf Accessed September 52011

[12]IDEC Instituto Brasileiro de Defesa do Consumidor, Em Foco:Acidente de consumo: relate seu caso 
http://www.idec.org.br/rev idec texto online.asp?pagina $=1 \&$ ordem $=1 \& i d=180$ Accessed September 52011

[13] IDEC Instituto Brasileiro de Defesa do Consumidor http://www.idec.org.br/ Accessed September 52011

[14]INMETRO Instituto Nacional de Metrologia http://www.inmetro.gov.br/ Accessed September 52011

[15]INMETRO Instituto Nacional de Metrologia http://www.inmetro.gov.br/consumidor/formulario_acidente.a sp Accessed September 52011

[16]R. Salponik, Estudo Clínico Epidemiológico das crianças vítimas de acidentes internadas em uma unidade de terapia intensiva pediátrica. 2004, 1v.170p. Dissertação (Mestrado em Medicina). Universidade Federal da Bahia. 2004.
[17]M.M. Soares and C.C. Bucich, Segurança do produto: reduzindo acidentes através do design. Estudos em Design 8 (2) (2000), 43-67.

[18]D. I Waisman, J. M Munez and J. Sanchez, Epidemiologia de los accidentes em la infância. Archivo de Pediatria del Uruguay, Montivideo, 73 (3) (2002), 161-170. http://www.scielo.edu.uy/scielo.php?pid=S0004$05842002000300009 \&$ script $=$ Sci arttext Accessed September 202011.

[19] W. Watson, L. Day, J. O Smmith and J. Lough, Consumer product realted injuries in old persons. Monash University Accident Research Centre- Report 162,1999. 